\title{
Stringent and growth-rate-dependent control of the gua operon of Escherichia coli K-12
}

\author{
Ian J. Davies and William T. Drabble
}

Department of Biochemistry, University of Southampton, Biomedical Sciences Building, Bassett Crescent East, Southampton SO16 7PX, UK
Author for correspondence: William T. Drabble. Tel: +441703 594279. Fax: +441703594459.

\begin{abstract}
The promoter of the gua operon has been located by transcript mapping using primer extension with reverse transcriptase. The surrounding nucleotide sequence has features characteristic of promoters under stringent and growthrate-dependent regulation, namely a GC-rich discriminator next to the -10 hexamer, an upstream AT-rich sequence (the UP element) and potential FISbinding sites. Transcriptional activity of the gua promoter was examined using transcriptional fusions to lacZ placed at a single chromosomal location. Expression from gua was reduced under stringent conditions in vivo, and varied with growth rate. Growth-rate control was independent of guaninemediated repression. A fusion in which the GC-rich discriminator was mutated by insertion of an AT-rich oligonucleotide was used to demonstrate the importance of this region in control. Both stringent and growth-ratedependent controls were abolished by the mutation. Other potential regulatory signals in the vicinity of the gua promoter are a pur operator (binding site for the PurR repressor), a gua operator, a DnaA-binding site and a CRP/FNR-binding sequence. The gua promoter lies back-to-back with the promoter for xseA (exonuclease VII), the two promoters being separated by only 20 bp.
\end{abstract}

Keywords: gua promoter, stringent control, growth-rate-dependent regulation, Escbericbia cali

\section{INTRODUCTION}

In Eschericbia coli, the flow of precursors into nucleic acids is a major metabolic commitment as RNA and DNA together comprise about one-quarter of the dry weight of the ceil (Neidhardt, 1987). Stable RNA (rRNA and tRNA) constitutes the latgest fraction of nucleic acids $(83 \%$ of the total for cells in balanced growth at $37^{\circ} \mathrm{C}$ in aerobic glucose minimal medium), DNA accounts for $13 \%$ of the total, and the remainder (approximately $4 \%$ ) is mRNA, which has a rapid rate of turnover. We can expect efficient regulatory mechanisms for ensuring balanced production of nucleic acid precursors (nucleotides) for stable RNA and DNA synthesis to have evolved within E. coli, because provision of these precursors is highly demanding of resources and energy expenditure.

The purine nucleotide GMP is formed from IMP by the action of IMP dehydrogenase and GMP synthetase. These enzymes are coded by the two contiguous genes ( $g u a B$ and gua $A$, respectively) of the gua operon. The nucleotide

Abbreviation: FIS, factor for inversion stimulation. sequence of the gua $B A$ operon has been determined (Teideman \& Smith, 1985; Thomas \& Drabble, 1985) but its regulatory features, including the promoter, have been only partially characterized (Thomas \& Drabble, 1985) (Fig. 1). The operon needs to be responsive to changes in the metabolic state of the cell by sensing (a) the presence of externally available guanine (which is used in preference to synthesis de novo), (b) the need for precursors of stable RNA and (c) the need for precursors of DNA. The operon must also be expressed in a way that achieves balanced production of GMP with that of AMP and with the pyrimidine nucleotides. The combination and interaction of these various controls provides a system of multivalent regulation for the gua operon.

General control of the genes involved in purine and pyrimidine biosynthesis is mediated by the PurR repressor protein (He et al., 1990; Meng et al., 1990), the product of purR, which binds to a 16 bp palindromic sequence (the pur operator) in the promoter regions of these genes (Schumacher et al., 1994). All the genes involved in GMP biosynthesis from 5-phosphoribosyl 1-pyrophosphate are regulated by PurR as shown from measurement of enzyme activity and/or expression from pur gene-lac $Z$ fusions in 
pur $\mathrm{R}$ mutant and pur $\mathrm{R}^{+}$host backgrounds. There is a threefold modulation of gua $B$ expression mediated by PurR (Meng et al., 1990). Evidence for PurR binding at the pur operator in these genes (with the exception of guaB $A$ ) has been provided by gel retardation and DNase I footprinting studies (He et al., 1990). The PurR corepressors have been identified as hypoxanthine and guanine (Choi \& Zalkin, 1992; Schumacher et al., 1994).

The production of IMP dehydrogenase and GMP synthetase is coordinately repressed by guanine in the growth medium and induced by adenine (Mehra \& Drabble, 1981; Spibey \& Drabble, 1981; Thomas \& Drabble, 1984). The range of gua operon expression from full repression to full derepression under conditions of guanine starvation is about 50 -fold (Spibey \& Drabble, 1981). This suggests an independent and specific system for controlling gua operon expression distinct from the PurR regulon.

We have reported that the guaBA operon is also regulated by DnaA protein (Tesfa-Selase \& Drabble, 1992). High intracellular concentrations of DnaA (achieved by inducing a multi-copy plasmid carrying the $d n a A$ gene fused to the tac promoter) reduce expression of the gia operon. Lowering the concentration of DnaA, either by sequestration with an oriC plasmid or by placing a temperaturesensitive $\operatorname{dna} A$ mutant at the restrictive temperature, results in increased expression of gua. Thus, transcriptional activity of the gua operon is sensitive to DnaA concentration and is thereby coupled to the DNA replication cycle.

As over $80 \%$ of the purine and pyrimidine nucleotides produced by $E$. coli are incorporated into stable RNA, the regulation of nucleotide biosynthesis would be expected to link into those mechanisms for regulating transcription of the genes for stable RNA. Control of stable RNA biosynthesis is through 'growth-rate-dependent' regulation and the associated 'stringent response' mediated by ppGpp (Baracchini \& Bremer, 1988). These are devices for reducing stable RNA production when bacteria are placed under conditions requiring fewer ribosomes and tRNA for protein synthesis (e.g. amino acid starvation and 'shift-down' from enriched to minimal medium).

In this paper, we identify and locate the gwa promoter by transcript mapping. This reveals several features within the surrounding sequence suggesting both transcriptional and translational control of guaB $A$ operon expression. In particular, the gua promoter has features characteristic of promoters under stringent and growth-rate-dependent regulation and indeed responds to stringent conditions and to alterations in the growth rate. In addition, we identify a DnaA box (binding site for Dna A protein), a potential pur operator, and a site with dyad symmetry which may be a candidate gua operator.

\section{METHODS}

E. coli strains and bacteriophages. ID1001 is derived from strain PL1087 (W3110 guaB67) (Gilbert \& Drabble, 1980) and carries a chromosomal gata point mutation and the plasmid
pMT101 (Thomas \& Drabble, 1984, 1985), pMT101 has a $2 \cdot 1 \mathrm{kbp}$ insertion of DNA incorporating the entire $\times 5 \mathrm{~s} A$ gene and a portion of gza $B$ extending to position 880 as numbered in Fig. 1 (approximately one-third of the guaB coding sequence). ID1001 was used for mRNA isolation. Strain LL309 (Gourse et al., 1986) was used to construct single-copy chromosomal fusions of the gua promoter to lacZ; ID1007 and ID1015 carry wild-type and mutant promoter-lac $Z$ fusions, respectively (see below). Phage arms for the construction of these fusions were provided by $\lambda$ RS205-S7 and 2459 (Miura et al., 1981). HB101 (Thomas \& Drabble, 1985) and JM103 (Yanisch-Perron $e t$ al., 1985) were the respective host strains for plasmids and phage M13mp18 (Yanisch-Perron et al., 1985).

Growth media. The minimal medium used is based on that of Vogel \& Bonner (1956) with the addition of thiamin hydrochloride $\left(5 \mu \mathrm{g} \mathrm{ml}^{-1}\right)$ and glucose $\left(4 \mathrm{mg} \mathrm{ml}^{-1}\right)$ or glycerol $\left(5 \mathrm{mg} \mathrm{ml}^{-1}\right.$ ) as carbon sources. The medium was enriched with Casamino acids ( 2 or $4 \mathrm{mg} \mathrm{ml}^{-1}$ ) or by adding $18 \mathrm{~L}$-amino acids (no valine or isoleucine) $\left(40 \mu \mathrm{g} \mathrm{ml}^{-1}\right.$ of each). M63 medium is described by Miller (1972). Bacteria were cultured routinely in L broth (Tesfa-Selase \& Drabble, 1992).

Preparation of RNA. The method used is adapted from Summers (1970). Bacteria (ID1001) were centrifuged from lateexponential-phase cultures grown in minimal medium $(80 \mathrm{ml})$ supplemented with glucose and Casamino acids, and washed

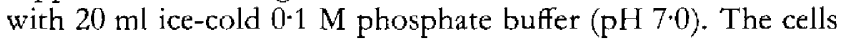
were resuspended in $20 \mathrm{ml}$ ice-cold protoplast buffer $15 \mathrm{mM}$ Tris/ $/ \mathrm{HCl}, \mathrm{pH} \mathrm{8.0;} 0.45 \mathrm{M}$ sucrose; $8 \mathrm{mM}$ EDTA; $80 \mu \mathrm{g}$ lysozyme $\mathrm{ml}^{-1}$ ) and incubated at $40^{\circ} \mathrm{C}$ for $5 \mathrm{~min}$. The cells were pelleted at $0^{\circ} \mathrm{C}$ and resuspended in $2 \mathrm{ml}$ lysis solution $(10 \mathrm{mM}$ Tris $/ \mathrm{HCl}, \mathrm{pH} 8.0 ; 10 \mathrm{mM} \mathrm{NaCl} ; 1 \mathrm{mM}$ sodium citrate; $1.5 \%$, SDS) plus $60 \mu \mathrm{l}$ diethylpyrocarbonate (DEPC), followed by incubation for $5 \mathrm{~min}$ at $37^{\circ} \mathrm{C}$. After cooling on ice, $1 \mathrm{ml}$ ice-cold saturated $\mathrm{NaCl}$ was added and the mixture was centrifuged at $5000 \mathrm{~g}$ for $10 \mathrm{~min}$ at $0{ }^{\circ} \mathrm{C}$. Fthanol $(9 \mathrm{ml})$ at $-20^{\circ} \mathrm{C}$ was added to the supernatant and RNA was allowed to precipitate for $4 \mathrm{~h}$ at $-20{ }^{\circ} \mathrm{C}$. The RNA was collected by centrifugation and stored at $-20^{\circ} \mathrm{C}$ as a suspension in $70 \%(\mathrm{v} / \mathrm{v})$ ethanol. Before use, the RNA suspension (1 ml) was centrifuged and the pellet was dissolved in $500 \mu \mathrm{l} \mathrm{DEPC-treated} \mathrm{water.} \mathrm{The} \mathrm{integrity} \mathrm{of}$ the RNA was checked by formaldehyde gel electrophoresis following heat denaturation $\left(60^{\circ} \mathrm{C}\right.$ for $\left.10 \mathrm{~min}\right)$. Contaminating DNA was removed with RNase-free DNase I, and protein by phenol extraction.

Preparation and labelling of oligodeoxyribonucleotides. Oligonucleotides were prepared by a solid-phase phosphoramidate method using an Applied Biosystems 381A DNA Synthesizer, and purified by reverse-phase HPLC. Primers $(0.6 \mu \mathrm{g}$ in $3 \mu \mathrm{l})$ were $5^{\prime}$-end-labelled by mixing with $5 \mu \mathrm{l} 10 \times$ kinase buffer $(0.5 \mathrm{mM}$ Tris $/ \mathrm{HCl}, \mathrm{pH} 7.6 ; 0.1 \mathrm{mM} \mathrm{MgCl}$; $1 \mathrm{mM}$ EDTA), $5 \mu \mathrm{l} 100 \mathrm{mM}$ spermidine, $2.5 \mu \mathrm{l} 1 \mathrm{M}$ DTT, $10 \mu \mathrm{l}$ $\left[\gamma^{32} \mathrm{P} \mid\right.$ ATP $\left(3.7 \times 10^{6} \mathrm{~Bq} ;>185 \mathrm{TBq} \mathrm{mmol}^{-1}\right), 21 \cdot 5 \mu$ l sterile water and $3 \mu \mathrm{l}$ (12 units) T4 polynucleotide kinase. The mixture was incubated at $37^{\circ} \mathrm{C}$ for $30 \mathrm{~min}$, then heated at $70^{\circ} \mathrm{C}$ for 10 min to inactivate the enzyme. Gel filtration through Sephadex G-50 was used to remove unincorporated ATP.

Transcript mapping by primer extension. Transcription start points were mapped by a method based on that of Wilson $e t$ al. (1987). Total cellulat RNA $(50 \mu \mathrm{g})$, prepared as described above, was mixed with $5^{\prime}$-end-labelled oligodeoxyribonucleotide primer (minimum of $5 \times 10^{5} \mathrm{~d}$.p.m.). The RNA mixture was precipitated from 2 vols ethanol at $-20^{\circ} \mathrm{C}$ by addition of $0.1 \mathrm{vol} 4 \mathrm{M} \mathrm{NaCl}$, collected by centrifugation, washed with $70 \%$ ethanol at $-20{ }^{\circ} \mathrm{C}$, dried at room temperature, and dissolved in $25 \mu \mathrm{l}$ hybridization buffer $(20 \mathrm{mM}$ 
Tris/ $\mathrm{HCl}, \mathrm{pH} 8 \cdot 0 ; 0 \cdot 1 \mathrm{M} \mathrm{KCl} ; 0 \cdot 1 \mathrm{mM}$ EDTA). The solution was heated at $100^{\circ} \mathrm{C}$ for 2 min and then placed at $37^{\circ} \mathrm{C}$ for $4 \mathrm{~h}$ to allow hybridization. At this stage, E. coli single-strand binding protein (Pharmacia) $(3.5 \mu \mathrm{g})$ was sometimes added to unravel any secondary structure in the RNA. The sample was cooled to room temperature and $25 \mu$ l of freshly prepared $2 \times$ buffer $\left(0.2 \mathrm{M}\right.$ Tris $/ \mathrm{HCl}, \mathrm{pH} 8.3 ; 20 \mathrm{mM} \mathrm{MgCl}_{2} ; 0 \cdot 1 \mathrm{M} \mathrm{KCl}$; $20 \mathrm{mM}$ DTT) containing $1 \mathrm{mM}$ each of dATP, dGTP, dCTP and TTP was added, together with 12.5 units avian myeloblastosis virus (AMV) reverse transcriptase. The sample was incubated at $37^{\circ} \mathrm{C}$ for $1 \mathrm{~h}$ then extracted with aqueous phenol. The primer extension products were precipitated by adding 2.5 vols $95 \%$ ethanol and placing the sample at $-70^{\circ} \mathrm{C}$ for $20 \mathrm{~min}$. The precipitate was collected by centrifugation, dissolved in $20 \mu \mathrm{L}$ DEPC-treated water, mixed with dye-loading solution and applied to $7 \mathrm{M}$ urea $/ 8 \%$ polyacrylamide gels for electrophoresis alongside DNA sequencing reactions using the same primers.

Insertion mutagenesis of the gua promoter. An AT-rich 14mer (5'AAAGTTAACTTTGC) was synthesized and selfhybridized by incubating $0.2 \mathrm{nmol}$ at $90^{\circ} \mathrm{C}$ for $2 \mathrm{~min}$ and then cooling to room temperature over a $2 \mathrm{~h}$ period. This generated SstII-compatible ends to enable insertion of the 14-mer into the unique SstII restriction site of pMT104 (Thomas \& Drabble, 1984, 1985). An internal HpaI site is also present in the sequence. The double-stranded oligomer $(0.05 \mathrm{nmol})$ was ligated to 0-01 nmol SitII-cut PMT104 DNA overnight at $15^{\circ} \mathrm{C}$ using 0.2 units T4 DNA ligase in a $10 \mu \mathrm{l}$ reaction. The ligated DNA was incubated at $37^{\circ} \mathrm{C}$ with $S_{s} t \mathrm{II}$ to digest any re-ligated pMT104 (vectors incorporating the mutagenic oligomer are $S_{s t} \mathrm{II}$ resistant). The constructed plasmid DNA was transformed into HB101 with selection for ampicillin resistance. Plasmid DNA (pID101) isolated from transformants was resistant to $S$ stII but, unlike pMT104, was sensitive to HpaI.

Construction of gua-lacZ transcriptional fusions. Plasmids pMT104 (Thomas \& Drabble, 1984, 1985) and pID101 (see preceding section) were digested separately with $A h u$. The 310 bp AluI fragment E (Thomas \& Drabble, 1984, 1985) from pMT104 and the corresponding $324 \mathrm{bp}$ fragment $E^{\prime}$ from pID101 (Fig, 1) were isolated by gel electrophoresis. These fragments were blunt-end ligated into $S$ maI-cut RF M13mp18 (20 ng cut M13mp18 RF DNA; $100 \mathrm{ng}$ fragment $\mathrm{E}$ or $\mathrm{E}^{\prime} ; 0 \cdot 4$ units T4 DNA ligase; $20 \mathrm{mM}$ Tris/ $\mathrm{HCl}, \mathrm{pH} 7.5 ; 1 \mathrm{mM} \mathrm{MgCl}$; $10 \mathrm{mM} \mathrm{DTT}$; $0.6 \mathrm{mM}$ ATP; in a total of $10 \mu \mathrm{l}$ ) with incubation oxernight at $15^{\circ} \mathrm{C}$. The ligated DNA was then used to transfect JM103 and white plaques were picked from X-Gal plates. The orientation of the cloned DNA was determined by sequencing using Sequenase (LS Biochemicai). This revealed that phage with fragments $E$ and $E^{\prime}$ in the required orientation for fusion to lai $Z$ had been constructed, and confirmed that fragment $\mathrm{E}^{\prime}$ contained the additional 14 bp from the inserted oligonucleotide.

The construction of transcriptional fusions of the gia promoter to lac $Z$ was achieved using two derivatives of phage $\lambda$ (Miura $t$ al., 1981). Digestion of DNA from $\lambda$ RS205-S7 (Bertrand et al., 1984) with $H$ indIII releases a fragment carrying lac $Z$ and $\operatorname{trp} A B^{\prime}$; this constituted the left arm of the fusion construction. The right arm was provided by digestion of $\lambda 459$ DNA with EcoRI. M13mp18 RF DNA carrying either fragment E or fragment $\mathrm{E}^{\prime}$ (with the gua promoter orientated towards the HindIII site of the M13mp18 polylinker) was treated in turn with HindIII and with EcoRI and fragments containing $\mathrm{E}$ and $\mathrm{E}^{\prime}$ were isolated by gel electrophoresis. Restriction enzymes were removed from these digests with aqueous phenol. The DNA fragments were mixed $\left(1 \cdot 3 \mu \mathrm{g}\right.$ of each $\lambda$ digest with $1.3 \mu \mathrm{g}$ fragment $E$ or $\left.E^{\prime}\right)$ to provide a molar excess of insert over the $\lambda$ arms, and ligated using T4
DN $A$ ligase at $15^{\circ} \mathrm{C}$ overnight. The ligated DNA was packaged in vitro as described by Rosenberg et al. (1985). The constructed $\lambda$ phage was used to infect the $\mathrm{Lac}^{-}$host LL309 (Gourse et al., 1986) and blue plaques were picked from X-Gal tryptone broth top agar plates. Lac ${ }^{+}$lysogens from within the plaques were purified on MacConkey agar. Single-copy lysogens were distinguished from multiple lysogens by $\beta$-galactosidase measurement using mid-exponential cultures in glucose minimal medium. Single lysogens (half the $\beta$-galactosidase activity of double lysogens) occurred at about fivefold greater frequency than double lysogens, as expected (Bertrand et al., 1984). It was noted that clones carrying the mutant $\left(E^{\prime}\right)$ gua-lac $Z$ fusion had only approximately $5 \%$ of the enzyme activity of those containing the wild-type gata promoter (E). Two strains were sclected as representative of single-copy wild-type (ID1007) and single-copy mutant (ID1015) gua-lac Z fusions.

$\boldsymbol{\beta}$-Galactosidase assay. The enzyme was assayed in cells lysed with chloroform and SDS and with ONPG as substrate (Miller, 1972). One unit (U) of $\beta$-galactosidase hydrolyses $1 \mu \mathrm{mol} O \mathrm{ONPG}$ $\min ^{-1}$ at $28^{\circ} \mathrm{C}$. 'The recorded $\beta$-galactosidase activities are means of assays from at least two independent cultures; the overall variation was not greater than $\pm 10 \%$.

Protein assay. The protein content of bacterial cells was determined by one of the following methods. When large numbers of measurements were to be made, samples $(1 \mathrm{ml})$ of cultures were centrifuged, and the cells washed, resuspended in $1 \mathrm{ml} 0.5 \mathrm{M} \mathrm{NaOH}$, and placed at $100^{\circ} \mathrm{C}$ for $5 \mathrm{~min}$. After cooling to room temperature, protein concentration was determined by the Lowry method. "The second procedure, used for smaller numbers of samples, involved sonication (two $30 \mathrm{~s}$ periods) of washed cells. Protein in the sonicates was measured by the bicinchoninic acid method of Smith et al. (1985).

\section{RESULTS}

\section{Locating the gua promoter by transcript mapping}

The guaBA operon has been cloned and sequenced but two conflicting locations for the gua promoter and the gua $B$ gene have been proposed. Using the $\mathrm{S} 1$ nuclease method for transcript mapping, Teideman \& Smith (1985) placed the promoter (P2, Fig. 1) between positions 12 and 43 in the nucleotide sequence with the gua $B$ coding region starting at A-242. Thomas \& Drabble (1985), however, placed the gua promoter (P1, Fig. 1) between positions 239 and 267. Placement at this position was based on the identification of small overlapping testriction fragments carrying promoter activity and on the exact fit of the -10 element of $\mathrm{P} 1$ to the consensus TATAAT. The initiation codon for $g u a B$ at $A-311$ was deduced from N-terminal sequencing of IMP dehydrogenase, and from the presence of a potential Shine-Dalgarno sequence (Thomas \& Drabble, 1985). The conflict between these two possible locations for the gua promoter has now been resolved by transcription mapping using primer extension by reverse transcriptase, with gua mRNA as template. For these experiments, the proportion of total mRNA which is gua mRNA was maximized by isolating RNA from strain ID1001 grown in guanine-free medium. This strain carries the chromosomal point mutation guaB67 and the plasmid pMT101. The plasmid has a $2 \cdot 1 \mathrm{kbp}$ insertion of DNA incorporating the entire $x s e A$ gene and gua $B$ to codon 190 (position 880 in the sequence as numbered in Fig. 1). A $26 \mathrm{kDa}$ plasmid-derived polypeptide (assumed to be the 


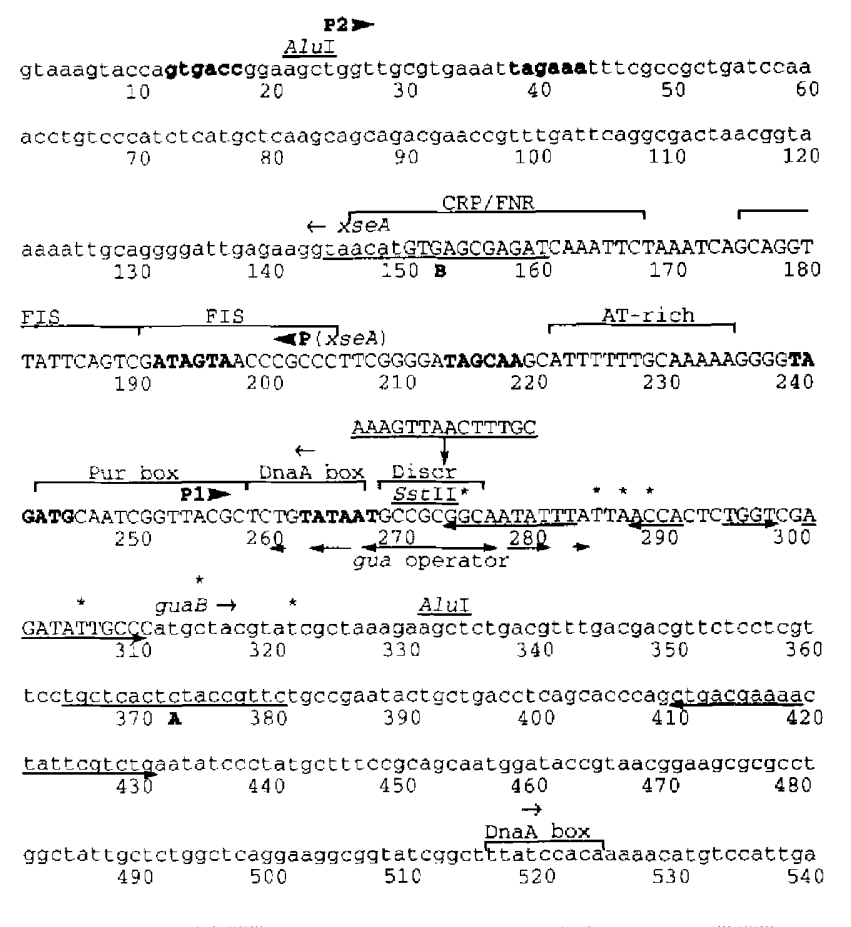

Fig. 1. Nucleotide sequence of the gua promoter region. The gua promoter (P1) and the divergent xseA promoter are indicated with -10 and -35 hexamers in bold-face type. P2 is another potential $\sigma^{70}$ promoter. The GC-rich discriminator implicated in stringent control is shown together with the mutagenic sequence inserted at the Sstll restriction site. Potential binding sites are identified for CRP and/or FNR, FIS, PurR, DnaA and for a putative gua repressor (at the gua operator). End-points of CDNA identified by extension of primers complementary to sequences $A$ and $B$ (underlined) are indicated by asterisks. Regions with dyad symmetry are marked by diverging arrows. Coding sequences for guaB (IMP dehydrogenase) and $x \operatorname{se} A$ (exonuclease VII) are shown in lowercase letters. Fragments $\mathbf{E}$ and $\mathbf{E}^{\prime}$ used for constructing gua-lac $Z$ fusions are between the two Alul restriction sites shown.

$\mathrm{N}$-terminal portion of IMP dehydrogenase) complements the defective chromosome-derived enzyme in vivo, resulting in prototrophic growth. These bacteria are derepressed during growth in guanine-free medium (Thomas \& Drabble, 1985), presumably to compensate for the low catalytic activity of the complemented enzyme.

The transcription start point for the gua operon was mapped by primer extension (see Methods). Two oligodeoxyribonucleotide 17-mers were synthesized with the sequences 5'-GAACGGTAGAGTGAGCA (primer A) and 5'ATCTCGCTCACATGT'TA (primer B). Primer A is capable of hybridizing with $\mathrm{mRNA}$ transcribed through nt 364-380 of the gud sequence (Fig. 1) and will therefore map transcripts initiated from both $\mathrm{P} 1$ and $\mathrm{P} 2$ as the scquence is downstream of both promoters. The cDN $A$ products of primer A extension using reverse transcriptase would be approximately 105 and $330 \mathrm{nt}$, respectively, for the two promoters. Primer $\mathrm{B}$ is capable of hybridizing with $m R N \Lambda$ transcribed through 144-160, that is downstream of $\mathrm{P} 2$ but upstrcam of $\mathrm{P} 1$, and will therefore map transcripts originating at $\mathrm{P} 2$ only, as indicated by the production of an approximately $100 \mathrm{nt}$ cDNA.

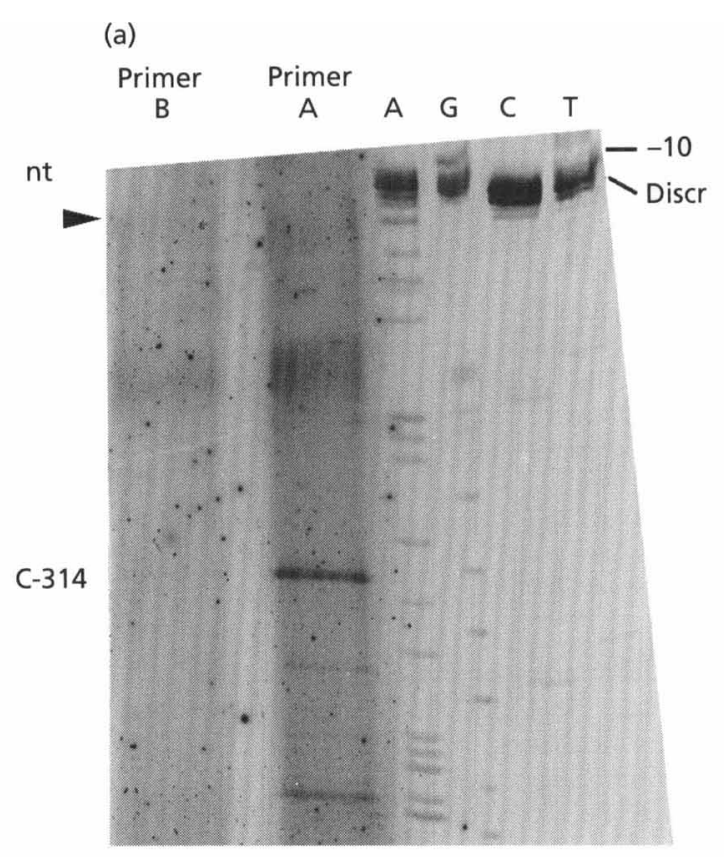

(b)

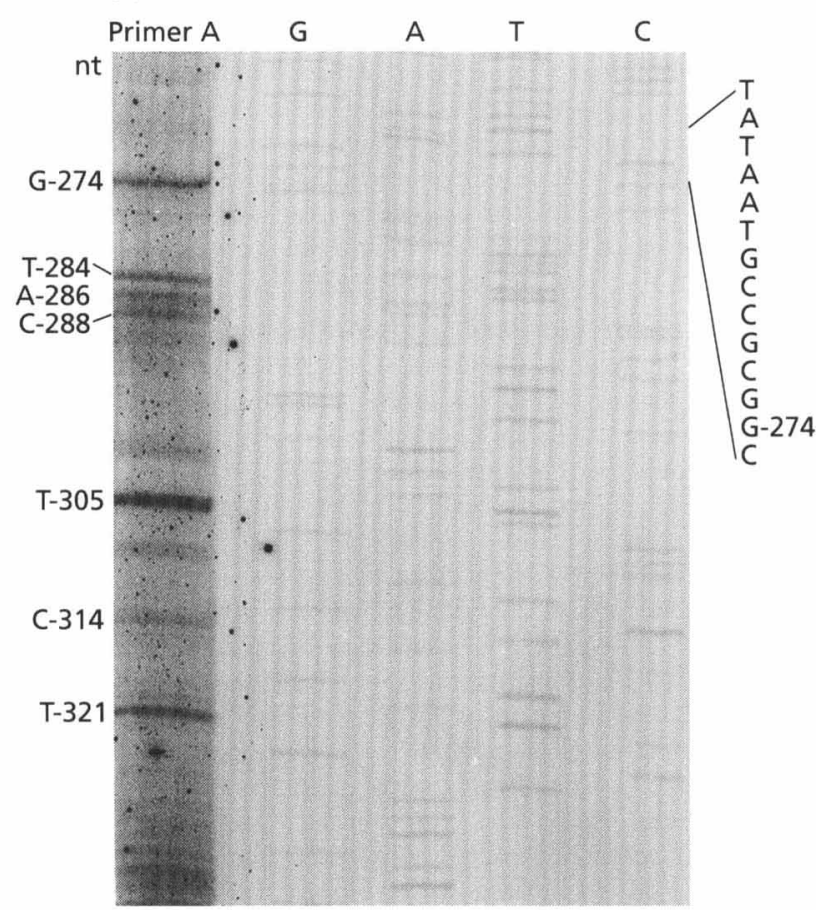

Fig. 2. Transcription mapping of the start point of gua mRNA by primer extension using primer $A$ and primer $B$ (see Fig. 1) in the absence (a) and presence (b) of single-strand binding protein. Sequencing reactions (using primer A) are shown alongside and are labelled as the coding strand (i.e. complementary to the primer extension products). 'Discr' is the GC-rich discriminator sequence. The arrow indicates the predicted position for a $110 \mathrm{nt}$ extension product of primer B for mRNA transcribed from promoter $\mathrm{P} 2$.

No cDNA was detected using primer B (Fig. 2a), so we conclude that no mRNA is transcribed upstream of and through the hybridization site of primer $B$ and hence $\mathrm{P} 2$ is 
not a functional promoter under the conditions assayed. However, the longest cDNA using primer A was only $67 \mathrm{nt}$. This does not correspond to a transcriptional start point close to promoter $\mathrm{P} 1$, but to position $\mathrm{C}-314$ in a region containing no typical promoter sequence. AMV reverse transcriptase is known to terminate at certain stable secondary structures (Tuerk ot al., 1988) such as hairpins. The potential to form stable secondary structure in the leader sequence of gua mRNA has been noted previously (Thomas \& Drabble, 1985) for a transcript starting at G-273 (Fig. 1). The stem-loop incorporates the first 37 nt of mRNA, so may cause reverse transcriptase to stop at C-314 (5 nt before the proposed hairpin). The primer extension reaction with primer $A$ was repeated with the addition of $E$. coli single-strand binding protein to unravel secondary structute in the gua mRNA. Under these conditions cDNA transcripts $60,67,76,93,95,97$ and $107 \mathrm{nt}$ long were detected (Fig. 2b). These correspond to termination of reverse transcription at the positions marked in Fig. 1 within the hairpin loop region. The longest cDNA detected corresponds to full-length transcripts originating at G-274 and thus identifies this nucleotide as the transcription start point for the gua promoter P1. The presence of a GC-rich 'discriminator' (Lindhal \& Zengel, 1986) sequence between the -10 element and the transcription start point suggested stringent regulation at this promoter and led to the experiments described in the following section.

\section{Transcriptional regulation of the gua promoter}

Transcriptional fusions of the gua promoter to $\operatorname{lac} Z$ were constructed to facilitate investigation of transcriptional control of the gua operon by stringent and growth-ratedependent regulation. The procedure involved cloning promoter-containing restriction fragments of DNA upstream of a promoter-less lac $Z$ gene carried on $\hat{\lambda}$ phage (see Methods). Following phage DNA assembly, in vitro packaging and infection of $\mathrm{Lac}^{-}$bacteria, single-copy $\mathrm{Lac}^{+}$lysogens were isolated. These lysogens contain a single-copy lac $Z$ gene, under control of the chosen ptomoter, integrated into the host genome at att $\lambda$. Two promoter-containing fragments were fused to lac $Z$; fragment E (Fig. 1) carrying the wild-type gua promoter and $\mathrm{E}^{\prime}$ the corresponding fragment into which the sequence 5'-AAAGT'TAAC'T'T'TGC had been inserted at the unique $\mathrm{GC}$-rich $S_{\text {st }} \mathrm{II}$ site adjacent to the -10 promoter hexamer. Two lysogens carrying these fusions (ID1007 and ID1015, respectively) were used in experiments to investigate the control mechanisms affecting gua expression.

The stringent response in bacteria occurs under conditions of amino acid starvation (Gallant et al, 1971). Using the lysogens ID1007 and ID1015, the effect of amino acid starvation on transcription initiated at the wild-type and mutant forms of the gua promoter was determined. Amino acid starvation was achieved by the addition of valine to cultures grown in the absence of isoleucine. Valine inhibits the first enzyme common. to isoleucine and valine biosynthesis and thereby starves bacteria of isoleucine (Freundich et al., 1962). The specific

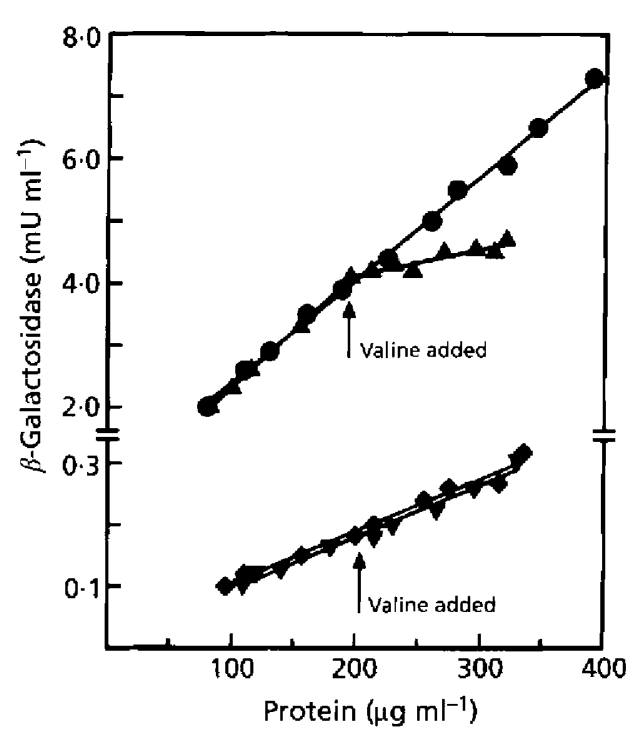

Fig. 3. Effect of amino acid depletion on the expression of $\beta$ galactosidase in guaB-lac $Z$ fusion strains. Bacteria were grown in M63 medium supplemented with glucose $\left(2 \mathrm{mg} \mathrm{ml}^{-\top}\right), \mathrm{MgSO}_{4}$ (1 $\mathrm{mM}$ ) and $1 \mu \mathrm{g} \mathrm{ml}^{-1}$ each of 18 L-amino acids (excluding isoleucine and valine). Medium (100 ml vols) was inoculated with $10 \mathrm{ml}$ overnight culture of $1 D 1007$ ( $)$. $\Delta$, wild-type gua promoter) or ID1015 (,$\nabla$, mutated gua promoter) grown in the same medium. Cultures were grown at $30^{\circ} \mathrm{C}$ with aeration (growth rates 0.95 and 0.90 doublings $h^{-1}$, respectively, for ID1007 and ID1015). Samples were removed periodically for $\beta$ galactosidase and protein assays. At mid-exponential growth, valine was added $(\boldsymbol{\Lambda}, \boldsymbol{\nabla})$ to a final concentration of $500 \mu \mathrm{g} \mathrm{ml}^{-1}$ to induce the stringent response (for these cultures growth rate gradually declined to zero over the course of $1 \mathrm{~h}$ following valine addition).

activity of $\beta$-galactosidase was measured with and without isoleucine starvation ( $\mathrm{Fig}$. 3). For bacteria growing normally (control culture), $\beta$-galactosidase formed a constant proportion of the cell protein (constant specific activity). However, after addition of valine the differential rate of synthesis of $\beta$-galactosidase fell by about $75 \%$ from that of the control culture. Hence expression of $\beta$ galactosidase is responding to stringent conditions in a manner that is predictable from the sequence determinants present at the promoter. Similar experiments with strain ID1015 indicated that isoleucine starvation had no effect on the specific activity of $\beta$-galactosidase (Fig. 3), indicating that mutation of the GC-rich discriminator region by insertion of an AT-rich sequence, while reducing the activity of the promoter, completely abolishes stringent regulation.

The two lysogens were grown in media that support a range of growth rates and the specific activity of $\beta$ galactosidase was determined during exponential growth (Fig. 4a). For the wild-type promoter fusion the specific activity of $\beta$-galactosidase increased with growth rate, showing that at higher growth rates the enzyme constitutes a larger fraction of the cell protein. $\beta$ Galactosidase specific activity for the culture growing at 1 doubling $\mathrm{h}^{-1}$ was almost twice that for the culture growing at 0.43 doublings $h^{-1}$. This is characteristic of 


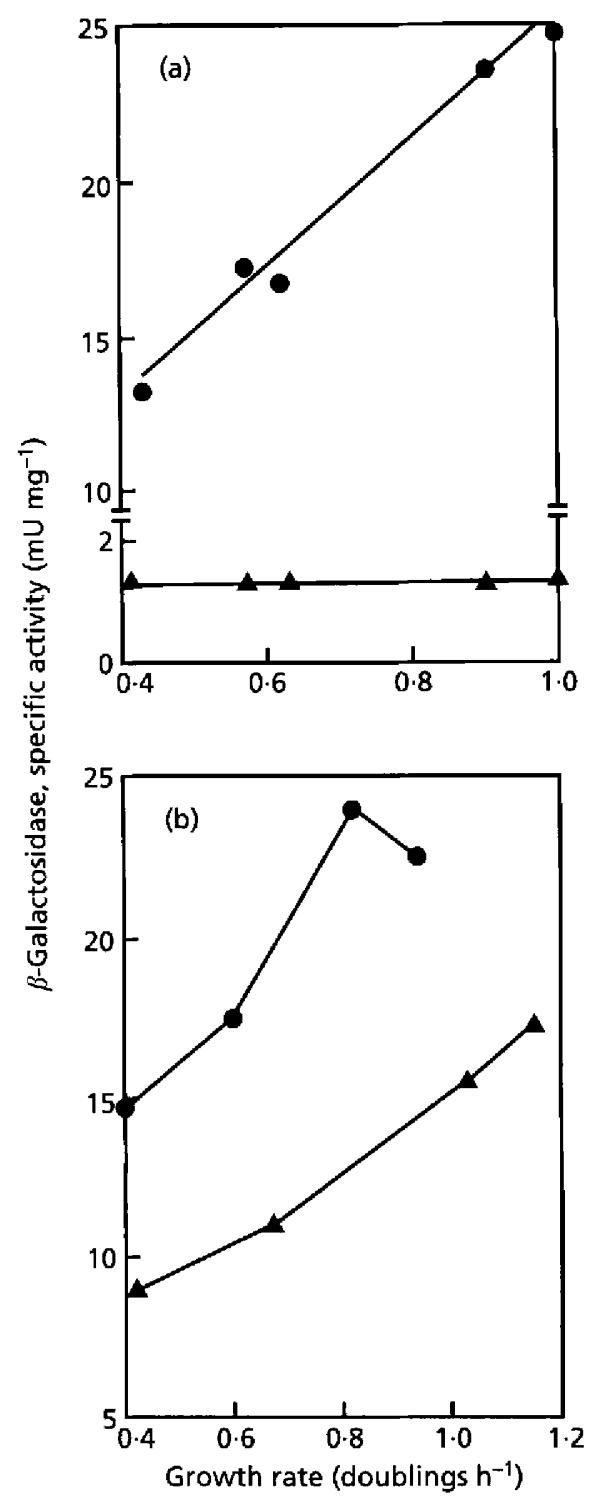

Fig. 4. (a) Effect of growth rate on the expression of $\beta$ galactosidase in guaB-lacZ fusion strains ID1007 (C, wild-type gua promoter) and ID1015 (A, mutated gua promoter). Increasing growth rates were achieved by growing bacteria in defined minimal medium supplemented with: glycerol (5 mg $\left.\mathrm{ml}^{-1}\right)$ and thiamin $\left(1 \mu \mathrm{g} \mathrm{ml}^{-1}\right)$; glucose $\left(4 \mathrm{mg} \mathrm{ml}^{-1}\right)$ and thiamin (1 $\left.\mu \mathrm{g} \mathrm{ml}^{-1}\right)$; glycerol $\left(5 \mathrm{mg} \mathrm{ml}^{-1}\right)$, thiamin $\left(1 \mu \mathrm{g} \mathrm{ml}^{-1}\right)$ and $18 \mathrm{~L}-$ amino acids $\left(40 \mu \mathrm{g} \mathrm{ml}^{-1}\right.$ of each, excluding isoleucine and valine); glucose $\left(4 \mathrm{mg} \mathrm{ml}^{-1}\right)$, thiamin and 18 amino acids as before; glucose $\left(4 \mathrm{mg} \mathrm{ml}^{-1}\right)$ and Casamino acids $\left(4 \mathrm{mg} \mathrm{ml}^{-1}\right)$. (b) Expression of $\beta$-galactosidase in ID1007 grown at different rates in the absence $(\boldsymbol{C})$ and presence $(\boldsymbol{A})$ of guanine $(40 \mu \mathrm{g}$ $\mathrm{ml}^{-1}$ ). Increasing growth rates were achieved by growing bacteria in defined minimal medium supplemented with: glycerol or glucose and thiamin [as in (a)]; glucose $\left(2 \mathrm{mg} \mathrm{ml}^{-1}\right)$, thiamin $\left(1 \mu \mathrm{g} \mathrm{ml}^{-1}\right)$ and Casamino acids $\left(2 \mathrm{mg} \mathrm{m}^{-1}\right)$; glucose $\left(2 \mathrm{mg} \mathrm{ml}^{-1}\right)$, thiamin $\left(1 \mu \mathrm{g} \mathrm{ml}^{-1}\right)$ and yeast extract $\left(2 \mathrm{mg} \mathrm{ml}^{-1}\right)$ (yeast extract contains some guanine derivatives). All cultures were grown at $30^{\circ} \mathrm{C}$ with aeration. At an $\mathrm{OD}_{600}$ of 0.4 , samples were removed for assay of protein and $\beta$-galactosidase. the products of genes that are under growth-ratedependent control (Miura et al., 1981), and indicates that the gua operon is under this form of regulation. The specific activity of $\beta$-galactosidase in the fusion strain carrying the insertion mutation showed no dependence on growth rate (Fig. 4a).

Guanine in the growth medium represses expression of the gua operon (Mehra \& Drabble, 1981). The effect of guanine on growth-rate-dependent control of the gua-lac $Z$ fusion was investigated (Fig. 4b). The presence of guanine led to a decrease of between 40 and $45 \%$ in the specific activity of $\beta$-galactosidase in each of the four media tested, but did not abolish the growth-rate-dependent response. This suggests that guanine repression is independent of the growth-rate response.

\section{DISCUSSION}

Primer extension with AMV reverse transcriptase was used to map the transcription initiation point of gua mRNA and thus identify P1 as the gua promoter (Fig. 1). On the basis of S1 nuclease mapping, it was proposed previously (Teideman \& Smith, 1985) that the gua promoter lies farther upstream at $\mathrm{P} 2$. This region of DNA does not, however, carry a functional promoter responding to guanine and adenine, as predicted for the gua promoter (Thomas \& Drabble, 1985). The region does contain several promoter-like sequences which may bind RNA polymerase in vivo and lead to the production of minor transcripts. These could protect DNA during $\$ 1$ mapping, particularly at high RNA:DNA ratios. Furthermore, promoter $\mathrm{P} 2$ is within the $x$ seA coding sequence (Chase et al., 1986) and is more distant than P1 from the start of the guaB coding region, which has been identified directly by $\mathrm{N}$-terminal sequencing of purified IMP dehydrogenase (Thomas \& Drabble, 1985). Promoter P1 has the preferred 17 bp separation of -35 and -10 hexamers, unlike P2 where the separation is $20 \mathrm{bp}$.

The gua mRNA leader has the potential for forming a stable stem-loop secondary structure $\left[\Delta G^{0}=-19 \cdot 2 \mathrm{kcal}\right.$ $\mathrm{mol}^{-1}\left(-80.6 \mathrm{~kJ} \mathrm{~mol}^{-1}\right)$ at $25^{\circ} \mathrm{C}$ ] incorporating the first $37 \mathrm{nt}$ of the transcript (Thomas \& Drabble, 1985). As the ribosome-binding site is sequestered in the stem-loop, this structure may be involved in regulating translation of gua mRNA as has been proposed for mRNA transcribed from pyrC (Kelln \& Neuhard, 1988). Formation of this stem-loop during the hybridization step in the transcriptmapping procedure explains the presence of truncated transcripts as AMV reverse transcriptase terminates prematurely at RNA hairpins (Tuerk et al., 1988), but some of the transcripts may have arisen from the copying of mRNA partially degraded at the $5^{\prime}$ end. Full-length cDNA was detected only when single-strand binding protein was added to unravel sccondary structure in the mRNA.

Examination of the nucleotide sequence in the vicinity of the gua promoter reveals features similar to those found in promoters for stable RNA. These promoters are subject to stringent control and growth-rate-dependent regu- 
lation, but no single conserved feature has been shown to confer these properties (Zacharias et al., 1990). Most highly conserved is a GC-rich sequence, known as the 'discriminator', downstream of and adjacent to the -10 hexamer. The consensus sequence for the discriminator is $\mathrm{NCNG} /{ }_{\mathrm{C}} \mathrm{C}^{\mathrm{G}} /{ }_{\mathrm{C}} \mathrm{CC}$, where the first nucleotide is next to the last $T$ of the -10 hexamer of the promoter (Lindhal \& Zengel, 1986). The gua discriminator matches this consensus at seven of the eight positions. Also conserved in stringently regulated promoters is a cis-acting AT-rich sequence (the UP element) located between -60 and -40 with respect to the transcription start site. This has been ascribed a role in transcriptional activation (Ross $e t$ al., 1993), improving RNA polymerase/promoter contact through DNA bending and compensating for the weak homology of these promoters with the -35 consensus (TTGACA). In addition, trans-activation by FIS has been recognized (Finkel \& Johnson, 1992). FIS binds to sequences found between -71 and -60 of many rRNA and tRNA genes and activates transcription when there is a change to conditions that can support higher growth rates (Ball et al., 1992). The AT-rich sequence and potential FIS sites are present upstream of the gua promoter (Fig. 1); however, the consensus for the FISbinding site (Finkel \& Johnson, 1992) is sufficiently redundant for the significance of the sites in gua to be considered only with caution pending further investigation.

In this study, we have presented experimental evidence both for stringent control and for growth-tate-dependent regulation of the gua promoter. Isoleucine starvation of the strain carrying a single-copy chromosomal gua-lac $Z$ fusion caused a $75 \%$ fall in $\beta$-galactosidase synthesis (similar to the decrease reported for the P1 promoters of rrn operons; Condon et al., 1992). Growth of the gua-lacZ fusion strain in defined media designed to support a range of growth rates showed that gua expression (measured as $\beta$-galactosidase specific activity) is subject to growth-ratedependent regulation.

Distuption of the gua discriminator by insertion of an ATrich linker removed stringent and growth-rate-dependent regulation. Similar effects, indicating the importance of the -1 to -10 region for stringent and growth-ratedependent regulation, have been observed following alterations to other promoters. Substitution of four GC base pairs by AT base pairs in the discriminator of the tyr $T$ promoter reduced stringent (Lamond \& Travers, 1985) and growth-rate control (Travers et al., 1986), as did alterations to the $r m B$ P1 discriminator sequence (Dickson et al., 1989). Changes to the discriminator sequence appear to produce diverse effects on promoter strength. The substitutions in the tyr $T$ promoter doubled its strength (Lamond \& Travers, 1985) but single insertions and deletions in the discriminator sequence of $r m B$ P1 reduced promoter activity down to $20 \%$ of wild-type activity (Gaal et al., 1989). Mutation of the gua discriminator with the AT-rich oligonucleotide resulted in a $90 \%$ reduction in promoter activity measured at a grow th rate of $\mu=0 \cdot 6$. This reduction in activity of the gua promoter may result partially from the effects of inserting a 14-mer on transcription initiation. The initiating nucleotide is altered from $G$ to $A$, and the mRNA leader is increased by $14 \mathrm{nt}$.

During the stringent response there is a sharp fall in the GTP pool (which is then maintained at half its normal size) with a concomitant, almost equimolar, increase of ppGpp (Gallant et al., 1970; Gallant \& Harada, 1969). Contraction of the GTP pool does not occur, however, if RNA synthesis is prevented by uracil starvation; in fact the GTP pool expands (Gallant \& Harada, 1969). During isoleucine (but not uracil) starvation the conversion of IMP to GMP is blocked because ppGpp is a strong competitive inhibitor of IMP dehydrogenase (Gallant et al., 1970, 1971; Pao \& Dyess, 1981). It is now apparent from our present work that contraction of the GTP pool during stringency may follow not only from enzyme inhibition by ppGpp but also from reduced transcription from the gua promoter.

As the primary function of purine and pyrimidine nucleotide biosynthesis is to provide precursors for stable RNA, stringent and growth-rate-dependent regulation of this synthesis is logical. In the absence of a need for stable RNA, it makes sense that synthesis of RNA precursors is curtailed. Apart from the gua promoter, the promoters of other genes involved in nucleotide biosynthesis show a close match to the GC-rich discriminator and may be stringently regulated. Indeed, experimental evidence has been presented for stringent regulation of pur $F$ (Makaroff \& Zalkin, 1985), pyrBI (Turnbough, 1983) and car $A B$ (Bouvier et al., 1984; Piette et al., 1984). Together with gua $B A$, these genes encode enzymes that occupy pivotal points in purine and pyrimidine nucleotide biosynthesis.

Confirmation of the guaBA promoter and +1 transcription initiation site justifies inspection of the surrounding sequence for features of potential regulatory significance. It is reported that the PurR repressor modulates guaB expression by about threefold (Meng et al., 1990). A putative 16 bp pur operator, with $11 / 16$ match to the consensus, can be identified. This is centred at C-249/G-250 within the gta promoter (Fig. 1). The full range of expression for the gua operon is, however, about 50-fold (Spibey \& Drabble, 1981), so a regulatory mechanism must exist that is independent of PurR, stringent and growth-rate-dependent control, but is sensitive to changes in the cytoplasmic guanine and adenine nucleotide pools (Mehra \& Drabble, 1981). The gua promoter region contains a sequence of imperfect dyad symmetry extending over $18-24$ bp centred at $G$ $271 / \mathrm{C}-272$ (Fig. 1). This sequence overlaps the promoter and is therefore located where binding of a gua-specific repressor protein could interfere with transcription initiation. Work is now in progress to isolate and characterize a DNA-binding protein specific for this gua 'operator'. Expression of the operon is sensitive to changes in cellular DnaA protein concentration (TesfaSelase \& Drabble, 1992). The gua promoter region has a DnaA box, the binding site for Dna $A$, with $8 / 9$ match to the consensus, although a consensus sequence box within the guaB coding region is also implicated in this regulation (F. Tesfa-Selase \& W. T. Drabble, unpublished results). 
The gua promoter lies in the back-to-back arrangement with the promoter for $x s e 1$ (encoding the mismatch repair enzyme cxonuclease VIl) (Chase et al., 1986). Only 20 bp separate the -35 hexamers of these promoters with 161 bp between the initiation codons of IMP dehydrogenase and exonuclease VII. Such close spacing of promoters may have regulatory significance (Beck \& Warren, 1988) and will lead to steric hindrance as RNA polymerase molecules attempt to bind simultaneously, especially if the two promoters lie on the same face of DNA, as in this example. Inactivation of either promoter would be expected to increase the activity of the other. Several examples of divergent promoters regulated by the binding of CRP protein have been identified (Kolb et al., 1993). A sequence with $17 / 22$ match with the consensus binding site for CRP (Kolb et al., 1993) lies at -117 with respect to initiation of gua transcription, but downstream of the divergent promoter for $x: A$. The core motif TGTGA of this site is conserved in the left half of the palind tome, but one difference in the right half confers the consensus core motif (TCAAA) for binding of FNR. It has been demonstrated (Bell et al., 1989; Jennings \& Beacham, 1993) that hybrid binding sites of this type respond to both CRP and FNR in vivo. The presence of CRP or FNR at the site may hinder binding of RNA polymerase to the $x$ se $A$ promoter and thus relieve competition at the gua $B A$ promoter; the relcvance, if any, of such a mechanism to the overall control of guaB $A$ and $x \in A$ expression is being investigated.

\section{ACKNOWLEDGEMENTS}

We thank Professor M. Nomura for providing bacteriai strains and bacteriophage. I. J.D. gratefully acknowledges financial support from the Medical Research Council.

\section{REFERENCES}

Ball, C. A., Osuna, R., Ferguson, K. C. \& Johnson, R. C. (1992). Dramatic changes in Fis levels upon nutrient upshift in Escherichia colk. J Bacteriol 174, 8043-8056.

Baracchini, E. \& Bremer, H. (1988). Stringent and growth control of rRNA synthesis in Eschericbia coli are both mediated by ppGpp. I Biol Chem 263, 2597-2602.

Beck, C. F. \& Warren, R. A. J. (1988). Divergent promoters, a common form of gene organization. Mirrobiol Rev 52, 318- 326.

Bell, A. I., Gaston, K. L., Cole, J. \& Busby, S. (1989). Cloning of binding sequences for the Escberichia coli transcription activators, FNR and CRP: location of bases involved in discrimination between FNR and CRP. Nulkic Aids Res 17, 3865-3874.

Bertrand, K. P., Postle, K., Wray, L. V., Jr \& Reznikoff, W. S. (1984). Consruction of a single-copy promoter vector and its use in analysis of tegulation of transposon Tn 10 tetracycline resistance detcrminant. J Bacteriol 158, 910-919.

Bouvier, J., Patte, J. \& Stragier, P. (1984). Multiple regulatory signals in the control region of the Escherichia coli ar $A B$ operon. Proc Nath Acad Sic USA 81, 41394143.

Chase, J. W., Rabin, B. A., Murphy, J. B., Stone, K. L. \& Williams, K. R. (1986). Frcberichia coli exonuclease VII: cloning and sequencing of the gene encoding the large subunit (xse A). J Biol Chem 261, 1492914935.
Choi, K. Y. \& Zalkin, H. (1992). Structural characterization and corepressor binding of the Escbericbia coli purine repressor. I Bacteriol 174, 6207-6214.

Condon, C., Philips, J., Fu, Z.-Y., Squires, C. \& Squires, C. L. (1992). Comparison of the expression of seven ribosomal RNA operons in Esibericbia coli. EMBO / 11, 4175-4185.

Dickson, R. R., Gaal, T., deBoer, H. A., de Haseth, P. L. \& Gourse, R. L. (1989). Identification of promoter mutants defective in growth-rate-dependent regulation of $r R N A$ transcription in Eschericbia coli. J Bacteriol 171, 4862-4870.

Finkel, S. E. \& Johnson, R. C. (1992). The Fis protein: it's not just for DNA inversion anymore. Mol Microbial 6, 3257-3265.

Freundlich, M., Burns, R. O. \& Umbarger, H. E. (1962). Control of isoleucine, valine, and leucine biosynthesis $\mathrm{I}$ : multi-valent repression. Proc Natl Acad Sci US A 48, 1804-1808.

Gaal, T., Barkei, J., Dickson, R. R., deBoer, H. A., deHaseth, P. L., Alavi, H. \& Gourse, R. L. (1989). Saturation mutagenesis of an Escherichia coli $\mathrm{rRNA}$ promoter and initial characterization of promoter variants. J Bacterio/ 171, 48524861

Gallant, J. \& Harada, B. (1969). The control of RN $A$ synthesis in Eschericbia coli III: the functional relationship between purine nucleoside triphosphate pool sizes and the rate of ribonucleic acid accumulation. J Biol Chem 244, 3125-3132.

Gallant, J., Ehrlich, H., Hall, B. \& Laffler, T. (1970). Analysis of the RC function. Cold Spring Harbor Symp Quant Biol 35, 397-405.

Gallant, J., Irr, J. \& Cashel, M. (1971). 'T he mechanism of amino acid control of guanylate and adenylate biosynthesis. J Biol Chem 246, $5812-5816$

Gilbert, H. J. \& Drabble, W. T. (1980). Complementation in vitro berwcen gttaB mutants of Escberichia coli K-12. J Gen Microbiol 117, $33-45$.

Gourse, R. L., deBoer, H. A. \& Nomura, M. (1986). DNA determinants of $\mathrm{rRMA}$ synthesis in $E$. coli: growth rate dependent regulation, feedback inhibition, upstream activation, antitermination. Cell 44, 197-205.

He, B., Shiau, A., Choi, K. Y., Zalkin, H. \& Smith, J. M. (1990). Gencs of the Escherichia coli pur regulon are negatively controlled by a repressor-operator interaction. J Bacteriol 172, 45554562.

Jennings, M. P. \& Beacham, I. R. (1993). Co-dependent positive regulation of the asmB promoter of Escberichia coli by CRP and the FNR protein: a molecular analysis. Mol Microbiol 9, 155-164.

Kelln, R. A. \& Neuhard, J. (1988). Regulation of pyrC expression in Salmonella syphimurium: identification of a regulatory rcgion. Mol Getz Genet 212, 287-294.

Kolb, A., Busby, S., Buc, H., Garges, S. \& Adhya, S. (1993). Transcriptional regulation by cAMP and irs receptor protein. Annu Rev Biocbem 62, 749-795.

Lamond, A. I. \& Travers, A. A. (1985). Genetically separable functional elements mediate the optimal expression and stringent regulation of a bacterial rRNA gene. Coll 40, 319326.

Lindhal, L. \& Zengel, J. M. (1986). Ribosomal genes in Escherichia coli. Annu Ru" Genet 20, 297-326.

Makaroff, C. A. \& Zalkin, H. (1985). Regulation of Escherichia coli purF : analysis of the control region of a pur regulon gene. $J$ Biol Chem 260, 10378-10387.

Mehra, R. K. \& Drabble, W. T. (1981). Dual control of the gua operon of tischericbia coli $\mathrm{K} 12$ by adenine and guanine nuclcotides. J Gen Microbiol 123, 27-37.

Meng, L. M., Kilstrup, M. \& Nygaard, P. (1990). Autoregulation of PurR repressor synthesis and involvement of pur $R$ in the regulation 
of purB, purC, purL, purMN and guaB $A$ expression in Escherichia coli. Eur J Biocbem 187, 373-379.

Miller, J. H. (1972). Experiments in Molecular Genetics. Cold Spring Harbor, NY: Cold Spring Harbor Laboratory.

Miura, A., Krueger, J. H., Itoh, S., deBoer, H. A. \& Nomura, M. (1981). Growth-rate-dependent regulation of ribosome biosynthesis in Escherichia coli: expression of the lac $Z$ and galK genes fused to ribosomal promoters. Cell 25, 773-782.

Neidhardt, F. C. (1987). Chemical composition of Escherichia coli. In Escherichia coli and Salmonella typhimurium: Cellular and Molecular Biology, pp. 3-6. Edited by F. C. Neidhardt, J. L. Ingraham, K. Brooks Low, B. Magasanik, M. Schaechter \& H. E. Umbarger. Washington, DC: American Society for Microbiology.

Pao, C. C. \& Dyess, B. T. (1981). Effect of unusual guanosine nucleotides on the activities of some Escherichia coli cellular enzymes. Biochim Biophys Acta 677, 358-362.

Piette, J., Nyunoya, H., Lusty, C. J., Cunin, R., Weyens, G., Crabeel, M., Charlier, D., Glansdorff, N. \& Piérard, A. (1984). DNA sequence of the car $A$ gene and the control region of $c a r A B$ : tandem promoters, respectively controlled by arginine and the pyrimidines, regulate the synthesis of carbamoyl phosphate synthetase in Escberichia coli K-12. Proc Natl Acad Sci USA 81, 4134-4138.

Rosenberg, S. M., Stahl, M. M., Kobayashi, I. \& Stahl, F. W. (1985). Improved in vitro packaging of coliphage lambda DNA: a onestrain system free from endogenous phage. Gene 38, 165-175.

Ross, W., Gosink, K. K., Solomon, J., Igarashi, K., Zou, C., Ishihama, A., Severinov, K. \& Gourse, R. L. (1993). A third recognition element in bacterial promoters: DNA binding by the $x$ subunit of RNA polymerase. Science 262, 1407-1413.

Schumacher, M. A., Choi, K. Y., Zalkin, H. \& Brennan, R. G. (1994). Crystal structure of LacI member, PurR, bound to DNA: minor groove binding by $\alpha$ helices. Science 266, 763-770.

Smith, P. K., Krohn, R. I., Hermansen, G. T., Mallia, A. K., Gartner, F. H., Provenzano, M. D., Fujimoto, E. K., Goeke, M. N., Olson, B. J. \& Klenc, D. C. (1985). Measurement of protein using bicinchoninic acid. Anal Biocbetm 150, 76-85.

Spibey, N. \& Drabble, W. T. (1981). Construction and characterization of guaB-lacZ fusions in Escherichia coli K12.J Gen Microbiol 126, 497-501.

Summers, W. C. (1970). A simple method for extracting RNA from
Eschericbia coli utilizing diethylpyrocarbonate. Anal Biochem 33, 459-463.

Teideman, A. A. \& Smith, J. M. (1985). Nucleotide sequence of the guaB locus encoding IMP dehydrogenase of Escherichia coli $\mathrm{K} 12$. Nucleic Acids Res 13, 1303-1316.

Tesfa-Selase, F. \& Drabble, W. T. (1992). Regulation of the gua operon of Eischerichia coli by the DnaA protein. Mol Gen Genet 231, 256-264.

Thomas, M. S. \& Drabble, W. T. (1984). Molecular cloning and characterisation of the gua regulatory region of Escherichia coli K12. Mol Gen Genet 195, 238 245.

Thomas, M. S. \& Drabble, W. T. (1985). Nucleotide sequence and organisation of the gua promoter region of Escherichia coli. Gene 36, $45-53$.

Travers, A. A., Lamond, A. I. \& Weeks, J. R. (1986). Alteration of the growth-rate-dependent regulation of Escherichia coli tyr $T$ expression by promoter mutations. J Mol Biol 189, 251-255.

Tuerk, C., Gauss, P., Thermes, C., Groebe, D. R., Gayle, M., Guild, N., Stormo, G., D'Aubenton-Carafa, Y., Uhlenbeck, O. C., Tinoco, I., Jr, Brody, E. N. \& Gold, L. (1988). CUUCGG hairpins: extraordinarily stable secondary structures associated with various biochemical processes. Proc Natl Acad Sci US A 85, 1364-1368.

Turnbough, C. L., Jr (1983). Regulation of Escbericbia coli aspartate transcarbamylase synthesis by guanosine tetraphosphate and $\mathrm{py}$ rimidine ribonucleoside triphosphates. J Bacteriol 153, 998-1007.

Vogel, H. J. \& Bonner, D. M. (1956). Acetylomithase of Escherichia coli: partial purification and some properties. I Biol Chem 218, 96-106.

Wilson, H. R., Chan, P. T. \& Turnbough, C. L., Jr (1987). Nucleotide sequence and expression of the pyrC gene of Escherichia coli K-12. J Bacteriol 169, 3051-3058.

Yanisch-Perron, C., Vieira, J. \& Messing, J. (1985). Improved M13 phage cloning vectors and host strains : nucleotide sequences of the M13mp18 and PUC19 vectors. Gene 33, 103-119.

Zacharias, M., Goringer, H. U. \& Wagner, R. (1990). The signal for growth rate control in $E$. coli is not restricted to a particular sequence motif within the promoter tegion. Nucleic Acials Res 18, 6271-6275.

Received 7 March 1996; revised 29 April 1996; accepted 22 May 1996. 